\title{
Innovative concept for personalized pattern design of safety equipment
}

\author{
DOI: 10.35530/IT.071.01.1620
}

SABINA OLARU

GABRIEL MIHĂILĂ

GEORGETA POPESCU

ADRIAN SĂLIȘTEAN

ANCA ANASTASIU

\section{ABSTRACT - REZUMAT}

\section{Innovative concept for personalized pattern design of safety equipment}

The competitive pressure of globalization is causing textile and garment manufacturers to lower production costs, increase their efficiency and to create leaner value-adding processes. To be able to cope with these changes, measures must be implemented, including the improvement of the internal organization, and the establishment of co-operations with external organizations to create a continuous supply-demand network.

The current paper presents the innovative concept for personalized pattern design of safety equipment applied within SC MATEI CONF GRUP SRL, highlighting the importance of personalization and its competitive advantages, from the idea to the prototype or product and testing it.

The research implementation used $3 D$ body scanning for analysis and determination of anthropometric measurements and conformation, 3D CAD technology for automatic rapid design of patterns in Made to Measure system, modelling and simulation of product in the virtual environment on customized mannequin highlighting the body-product correspondence.

Keywords: innovation, safety equipment, 3D body scanning, virtual simulation

\section{Concept inovativ de proiectare personalizată a echipamentelor de protecție}

Presiunea competitivă a globalizării determină producătorii de produse textile și de îmbrăcăminte să reducă costurile de producție, să crească eficiența și să creeze valoare adăugată. Pentru a putea face față acestor provocări, este imperios necesar să se implementeze măsuri precum optimizarea organizării interne și cooperarea cu organizații externe pentru crearea unei rețele continue de cerere și ofertă.

Lucrarea prezintă conceptul inovativ de proiectare personalizată a echipamentelor de protecție aplicat în cadrul companiei SC MATEI CONF GRUP SRL, cu evidențierea avantajelor competitive, de la idee la realizarea prototipului sau produsului și testarea acestuia.

Implementarea activităților de cercetare a presupus utilizarea scanării $3 D$ a corpului pentru analiza și determinarea dimensiunilor antropometrice și conformației, cât și a tehnologiei CAD 3D pentru proiectarea automată rapidă a tiparelor realizate în sistem Made to Measure, modelarea și simularea produsului în mediul virtual pe manechin personalizat, evidențiind corespondența corp-produs.

Cuvinte-cheie: inovare, echipament de protecție, scanare 3D a corpului, simulare virtuală

\section{INTRODUCTION}

The competitive pressure of globalization is causing textile and garment manufacturers to lower production costs, increase their efficiency and to create leaner value-adding processes. To be able to cope with these changes, measures must be implemented, including the improvement of the internal organization, and the establishment of co-operations with external organizations to create a continuous supply-demand network. As a result, production logistics as well as information and communication technologies have gained importance, in order to keep job functions requiring higher qualifications within Europe [1-3].

Clothing products and safety equipment are ideal for personalization and customization according to consumer requirements, which do not fit into standard sizes (body size and atypical conformations or special requirements) and are an important niche for the garments sector [4-7].

The current paper presents the innovative concept for personalized pattern design of safety equipment applied within SC MATEI CONF GRUP SRL, highlighting the importance of personalization and its competitive advantages, from the idea to the prototype or product and testing it.

The beneficiary Company, SC MATEI CONF GRUP SRL has experience of 12 years in the industry of individual protective equipment. This vast experience allows the development of protection solutions dedicated to each client. The main object of activity of the company is the production and marketing of safety equipment of category I - simple design; category II - neither of simple design nor of complex design; category III - complex design, both for the national and international market. The company MATEI CONF 
GRUP has the mission declared to offer solutions of protection of the highest degree of performance, through the professionalism and the dedication shown towards partners [8].

The introduction of the innovative concept for personalized pattern design of safety equipment within SC MATEI CONF GRUP SRL represents a complex process, which includes a multitude of activities, which have as final objective the obtaining of optimal correspondence between the shape of the studied body/subject and the safety equipment.

To address the objectives of the work the following steps were performed:

1. Introducing a new IT application in the design of personalized equipment, by 3D scanning the subject with dimensions outside the size standards.

2. After scanning, the system can automatically extract from the scanned body (virtual) over 100 dimensions.

3. Check the accuracy of the 3D scanner and the software for extracting anthropometric dimensions. For the subject studied a measurement protocol was generated, which facilitates the determination of the size of the garments and whether or not they fit in the size standards.

4. Analysis of the individual particularities of the body, necessary in designing personalized patterns.

5. Analysis and selection of the model of the safety equipment, found in the portfolio of the beneficiary company SC MATEI CONF GRUP SRL.

6. Verification of the method of designing the patterns using the software of automatic design by making the patterns, based on the individual body dimensions. The results of this verification are the patterns designed with Gemini Pattern Editor, the Made-tomeasure module, for the selected safety equipment. 7. Verification of the pattern matching, according to the individual dimensions of the body, by modelling 2D/3D patterns and simulating the safety equipment on the body or the virtual mannequin, parameterized to the dimensions of the selected body.

8. The dimensional correspondence of the bodyproduct and the draping mode have been verified realistically, by wearing the safety equipment and viewing the match.

\section{ANTHROPOMETRIC DIMENSIONS ANALYSIS}

The studied subject was scanned using the body scanner 3D VITUS XXL and the measurement protocol and virtual body or parameterized virtual mannequin (figure 1) were generated, which were the basis for designing the personalized patterns in Made-to-Measure system. The selected subject has the following main body dimensions extracted from the measurement protocol:

- Body height (Ic) $172 \mathrm{~cm}$;

- Bust circumference (Pb) $129 \mathrm{~cm}$;

- Waist circumference $(\mathrm{Pt}) 122 \mathrm{~cm}$;

- Hip circumference (Ps) $120 \mathrm{~cm}$.

According to this data, it was noticed that the bust circumference is placed in the superior limit of stan-

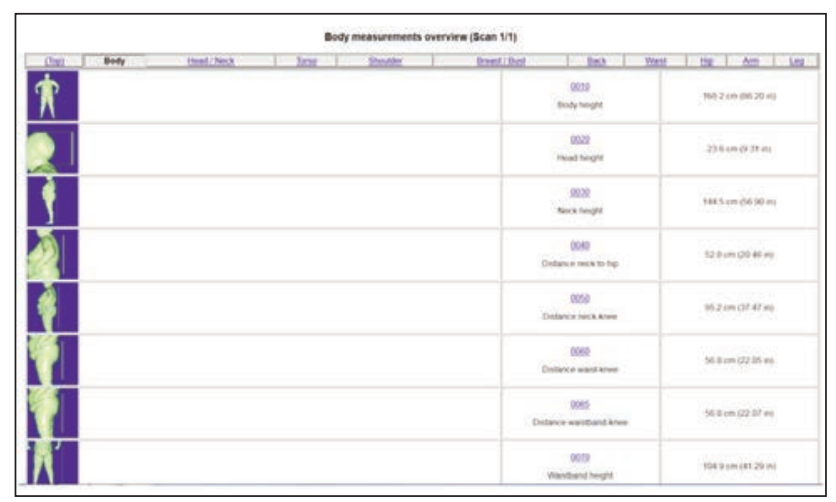

Fig. 1. Measurement protocol resulted from the 3D body scanning

dardized values according to the standard SR 13545 - Clothing. Women's Body Measurement and Garment Sizes [9]. In this standard, the maximum height of the body is $190.9 \mathrm{~cm}$. Also, the maximum standard circumference of the bust has a value of $128 \mathrm{~cm}$.

\section{PERSONALIZED DESIGN OF SAFETY EQUIPMENT}

Safety equipment protects the health and even the lives of millions of workers and professionals who are exposed to dangerous situations every day. This equipment must offer a delicate balance between the required level of protection, reduced weight and comfort during wear for several hours without impact on work performance.

In the study, the model of the safety equipment was analysed and selected, which was then customized by the innovative technological design and production solutions. The company SC MATEI CONF GRUP $\mathrm{SRL}$ selected the Overalls suit with chest and waist pants, which is in its portfolio and has been developed according to the corresponding technical description.

The costume is made in a combination of colours: light blue with navy blue and blue with red and consists of the blouse, chest trousers and waist support pants (figure 2). The overalls suit with chest pants and waist pants are worn by the operative personnel in the repair, maintenance and inspection activities of water pipes.

The blouse consists of breasts, back, drawstring, sleeves, collar, pockets and slit. The top of the blouse is blue (drinking water) or red (waste water). Above the horizontal seams of application of the pockets, the microfilm reflective tape is applied, throughout the width of the breasts (2 rows).

The chest trousers consist of the front, back, chest and straps. The trousers are provided in the frontal side with two knees made of corduroy navy blue material, resistant to wear. Inside them there are inserted foam shields for protection that closes with Velcro tape. At the end, the pants are provided with two straps of microfilm horizontal reflectors. The sides are provided with rib knit for adjusting the waist pants and giving the movement lightness. The structure of 
the knit is rib $1 \times 1$, which ensures the return to the useless form after a movement.

The trouser with waist support is made from the outside of waterproof blue material and is composed of the following benchmarks: front, back, waist and lining for inside pants.

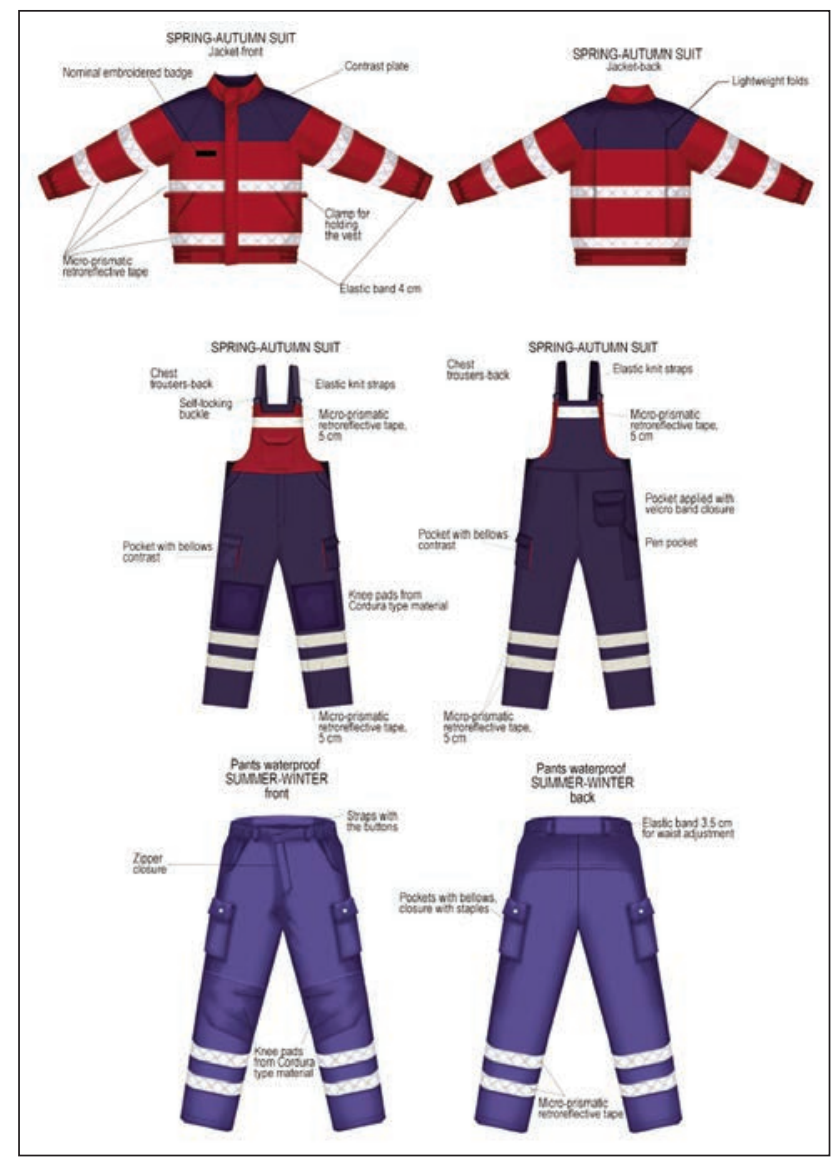

Fig. 2. Overalls suit with chest and waist pants
The costume was made from fabric 35\% PES, 64\% TENCEL and $1 \%$ AS, the blue color with the mass of $205 \mathrm{~g} / \mathrm{m}^{2}$.

Physical-mechanical and physical-chemical characteristics of the fabric were determined in the accredited laboratories of INCDTP (table 1). The elaborated test reports were used in textile material characterization in the $3 \mathrm{D}$ simulation.

The underwear coupled with the Overalls suit with chest and waist pants is made from TENCEL ${ }^{\text {TM }}$ Lyocell that naturally manage the transportation of moisture, contributing to breathable fabrics that provide a less favourable environment for bacterial growth, offering better hygienic qualities.

The design of the basic and model patterns for the selected safety equipment was based on the geometric method of pattern construction, using Gemini Pattern Editor's special CAD design software, the Made-to-Measure module. In this module, basic patterns are created for each type of clothing item, which are then modified by specific algorithms, depending on the model of the safety equipment selected and the dimensions of the body taken from the measurement protocol (figure 3).

Verification of personalized patterns matching, designed according to individual body dimensions, was accomplished by modelling 2D/3D patterns and simulating safety equipment on the parameterized mannequin, by using Optitex PDS software for visualization, modelling and fitting the virtual body of the prototype. The virtual try-on system involves transferring and fitting safety equipment to human body with various shapes and postures, with grade preservation. To achieve this goal, safety equipment must be treated as elastic models and their deformation is controlled by the laws of dynamics [10].

\begin{tabular}{|c|c|c|c|c|}
\hline \multicolumn{5}{|c|}{ PHYSIC-MECHANICAL AND PHYSIC-CHIMICAL CHARACTERISTICS OF FABRIC (SELECTION) } \\
\hline \multicolumn{2}{|c|}{ Characteristic } & UM & $\begin{array}{l}\text { Values obtained in the } \\
\text { accredited laboratories } \\
\text { of INCDTP }\end{array}$ & Reference document \\
\hline \multicolumn{2}{|l|}{ Mass } & $\mathrm{g} / \mathrm{m}^{2}$ & $205 \pm 5$ & SR EN 12127:2003 \\
\hline \multicolumn{2}{|l|}{ Weave } & - & Diagonal 3/1 & SR 6431:2012 \\
\hline \multicolumn{2}{|c|}{ Warp density } & threads $/ 10 \mathrm{~cm}$ & $345 \pm 5$ & SR EN 1049-2/2000 \\
\hline \multicolumn{2}{|l|}{ Weft density } & threads $/ 10 \mathrm{~cm}$ & $265 \pm 5$ & SR EN 1049-2/2000 \\
\hline \multicolumn{2}{|c|}{ Tensile strength warp } & $\mathrm{N}$ & 950 & SR EN ISO 13934-2013 \\
\hline \multicolumn{2}{|c|}{ Tensile strength weft } & $\mathrm{N}$ & 900 & SR EN ISO 13934-2013 \\
\hline \multicolumn{2}{|c|}{ Tear strength warp } & $\mathrm{N}$ & 50 & $\begin{array}{c}\text { SR EN ISO 13937-1: } \\
\text { 2001/AC:2006 }\end{array}$ \\
\hline \multicolumn{2}{|c|}{ Tear strength weft } & $\mathrm{N}$ & 40 & $\begin{array}{c}\text { SR EN ISO 13937-1: } \\
\text { 2001/AC:2006 }\end{array}$ \\
\hline \multirow{3}{*}{$\begin{array}{l}\text { Colour } \\
\text { fastness to }\end{array}$} & $\begin{array}{l}\text { perspiration } \\
\text { acid } \\
\text { alkaline }\end{array}$ & level & $\begin{array}{l}4 \\
4\end{array}$ & SR EN ISO 1 05-E 04:2013 \\
\hline & \begin{tabular}{|r|} 
rubbing dry \\
wet
\end{tabular} & & $\begin{array}{l}3 \\
3 \\
\end{array}$ & SR EN ISO 105-X12:2003 \\
\hline & light & & 4 & SR EN ISO 105-802:2015 \\
\hline
\end{tabular}




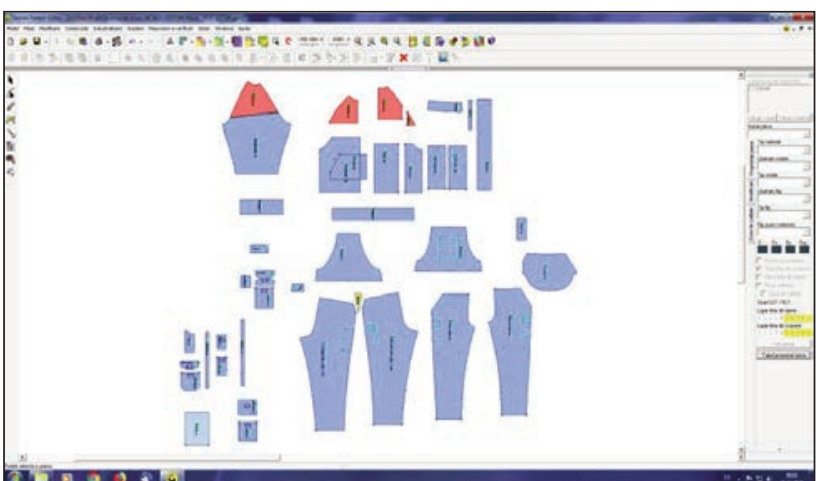

Fig. 3. The design of customized patterns of Overalls suit in Gemini Pattern Editor

Transforming patterns designed with the Gemini Pattern Editor into Optitex PDS from 2D to 3D, to obtain the virtual prototype of customized safety equipment was done in the following stages:
- parameterizing a virtual mannequin according to the anthropometric dimensions resulting from body measurement;

- shaping the surface of the patterns to obtain the 3D shape of the product with the addition of sewing lines and guide points (figure 4);

- introduction of information about the materials from which the work equipment is made (fibrous composition, drape, shrinkage, mass etc.);

- virtual try-on of the product on the virtual mannequin (figure 5);

- checking and modifying the pattern to ensure bodyproduct correspondence.

In order to check the body-to-product correspondence, the software has a function that shows the degree of ease/adjustment of the product on the body, called the Tension Map (figure 6), in which the red colour shows that the product presses the body, the blue colour shows high ease and green colour

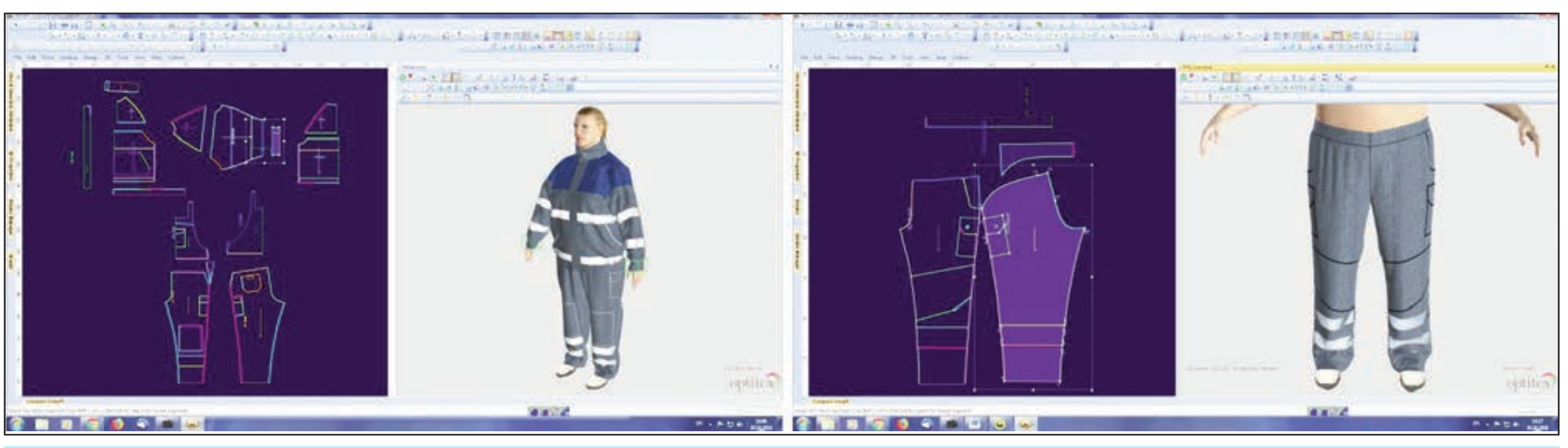

Fig. 4. The 2D patterns of the customized Overalls sit with seam lines
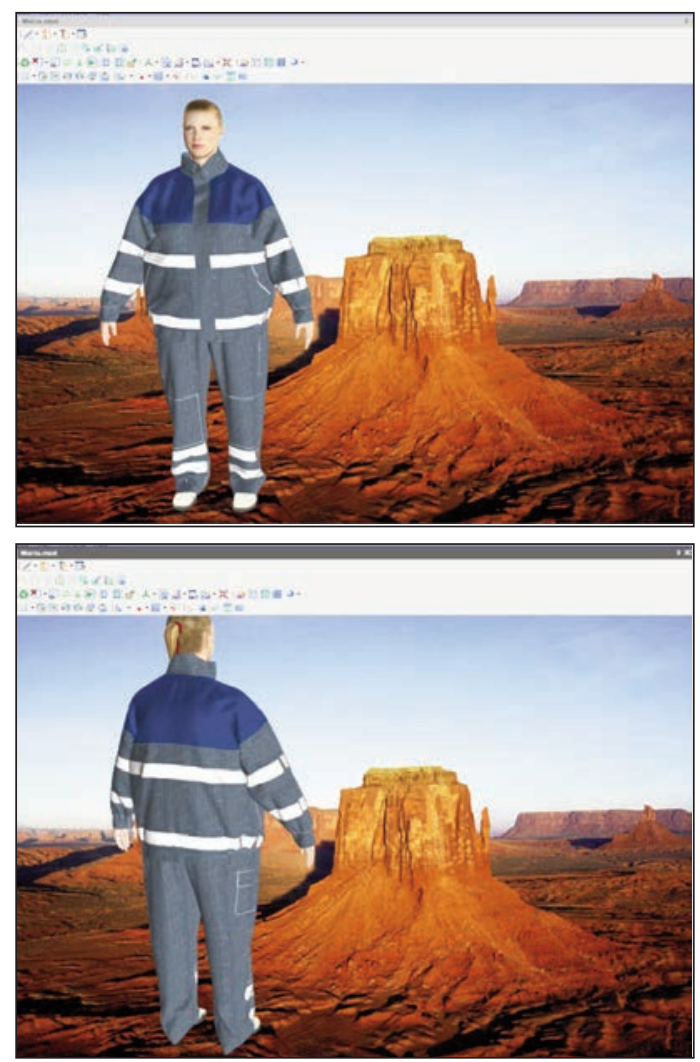

Fig. 5. Virtual try-on and verification of the customized safety equipment
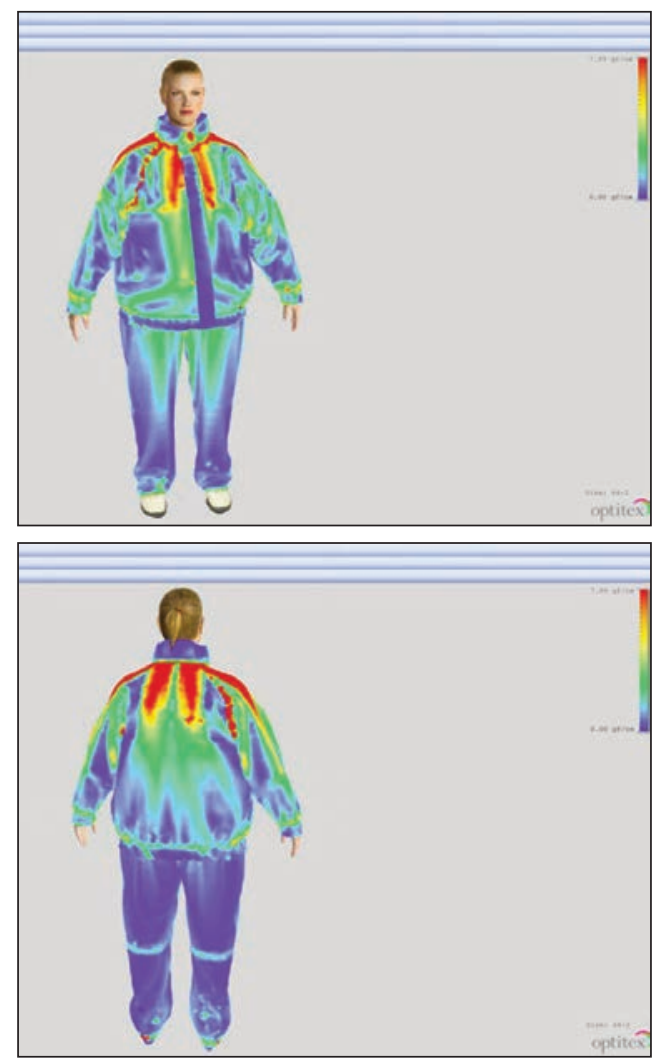

Fig. 6. Tension map for the overalls suit pattern verification 
shows that the product corresponds to the dimensions. Thus, it can be seen that the jacket product corresponds dimensionally.

Also, the chest and waist trousers fit on the waist line and are slightly wide on the hips line and at the end. The degree of ease indicated by the simulation software is justified by the patterns chosen for the jacket and the trousers that have a semi-rigid figure on the body. With this information, the designer could return to $2 \mathrm{D}$ patterns by making the necessary corrections. The real prototype of personalized safety equipment selected by the beneficiary company SC MATEI CONF GRUP SRL was tested on the actual body of the subject. Following the test, it was found that the outfit corresponds dimensionally, without forming unsightly creases or folds and without creating discomfort in wearing.

\section{CONCLUSIONS}

By action of customization it is understood individuality, customization and awareness, that each wearer has different conformation and carries out specific activities. Customized safety equipment involves the dimensional and conformational aspects of the body, respectively the product size as well as the qualitylinked functionality criterion, aspects regarding its wearability and protection tested in accredited laboratories, the effects over the individual comfort.

The research implementation used 3D body scanning for analysis and determination of anthropometric measurements and conformation, 3D CAD technology for automatic rapid design of patterns in made to measure system, modelling and simulation of product in the virtual environment on customized mannequin highlighting the body-product correspondence. These recent technological advances lead to a restructuring of the clothing industry, increasing the capacity to efficiently and readily satisfy the requests of each customer or even to produce clothing items with increasingly more efficient services for the client.

\section{ACKNOWLEDGEMENTS}

This work was supported by a grant of the Romanian Ministry of Research and Innovation, CCCDI - UEFISCDI, project number PN-III-P2-2.1-Cl-2018-0912, within PNCDI III. The publication of the paper is funded by the Ministry of Research and Innovation within Program 1 - Development of the national RD system, Subprogram 1.2 - Institutional Performance - RDI excellence funding projects, Contract no. 6 PFE/2018.

\title{
REFERENCES
}

[1] Park, H.-S., From Automation to Autonomy - a New Trend for Smart Manufacturing, In: DAAAM International Scientific Book 2013, Chapter 03, 2013, 075-110

[2] Zulch, G., Koruca, H.I., Borkircher, M., Simulation-supported change process for product customization - A case study in a garment company, In: Computers in Industry, 2011, 62, 568-577

[3] Tudor, L., Change in Textile and Clothing Industry, In: Industria Textila, 2018, 69, 1, 37-43, http://doi.org/10.35530/IT.069.01.1449

[4] Li, P., Chen, J.H., A model of an e-customized co-design system on garment design, In: International Journal of Clothing Science and Technology, 2018, 30, 5, 628-640

[5] Olaru, S., Filipescu, E., Niculescu C., Filipescu E., Morphological assessment of human body for clothing patterns design, In: Industria Textila, 2013, 64, 5, 254-259

[6] Dong, M., Hong, Y., Zhang, J., Liu, K., Wagner, M., Jiang, H., A body measurements and sensory evaluation-based classification of lower body shapes for developing customized pants design, In: Industria Textila, 2018, 69, 2, 111-117, http://doi.org/10.35530/IT.069.02.1381

[7] Rudolf, A., Stjepanovič, Z., Cupar, A., Designing the functional garments for people with physical disabilities or kyphosis by using computer simulation techniques, In: Industria Textila, 2019, 70, 2, 182-191, http://doi.org/10.35530/IT.070.02.1592

[8] https://www.mateiconfgrup.ro/, Accessed: 2.05.2019

[9] SR 13545:2010. Clothing. Women's Body Measurement and Garment Sizes

[10] Avădanei, M., Loghin, C., Dulgheriu, I., 3D pattern design of products with special destination, In: International Symposium in Knitting and Apparel ISKA 2013, 21-22 June 2013, Iaşi, Romania, ISSN 2069- 1564, 2013, 173-180

\section{Authors:}

\section{OLARU SABINA ${ }^{1}$, POPESCU GEORGETA ${ }^{1}$, ANASTASIU ANCA ${ }^{2}$,} MIHĂILĂ GABRIEL ${ }^{2}$, SĂLIȘTEAN ADRIAN ${ }^{1}$

\author{
${ }^{1}$ National R\&D Institute for Textiles and Leather, Lucretiu Patrascanu Street, no. 16, sector 3 \\ Postal code 030508, Bucharest, ROMANIA \\ e-mail: office@incdtp.ro \\ ${ }^{2}$ SC MATEI CONF GRUP SRL, Balaria Street, no. 4, Bucharest, ROMANIA, \\ e-mail: anca.anastasiu@mateiconfgrup.ro \\ Corresponding author: \\ POPESCU GEORGETA \\ e-mail: georgeta.popescu@incdtp.ro
}

